\title{
Atmospheric boundary layer characteristics over the Pearl River Delta, China, during the summer of 2006: measurement and model results
}

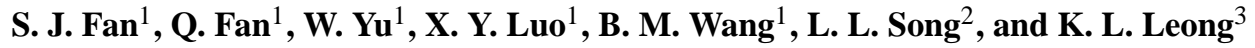 \\ ${ }^{1}$ Department of Atmospheric Sciences, Sun yat-sen University, Guangzhou, 510275, China \\ ${ }^{2}$ Climate Center of Guangdong Province, Guangzhou, 510080, China \\ ${ }^{3}$ Macao Meteorological and Geophysical Bureaus, Macao, China
}

Received: 6 July 2010 - Published in Atmos. Chem. Phys. Discuss.: 9 February 2011

Revised: 24 May 2011 - Accepted: 26 May 2011 - Published: 4 July 2011

\begin{abstract}
As part of the PRIDE-PRD2006 intensive campaign, atmospheric boundary layer (ABL) measurements were performed in Qingyuan, Panyu, and Xinken over the Pearl River Delta (PRD) on 1-30 July 2006. During the summer, the surface winds over the PRD are generally controlled by the south, usually with vertical wind shear at a height of approximately $800 \mathrm{~m}$. Subsidence and precipitation from a tropical cyclone affects the air quality of the PRD. Under subsidence, wind speed in the ABL and the height of the $\mathrm{ABL}$ decrease and result in high-level concentrations. When the background wind speed is small or calm, the wind profile in Panyu and Xinken changes dramatically with height, which is perhaps caused by local circulation, such as sealand breezes. To better understand the ABL of the PRD, simulations that used the Weather Research and Forecasting (WRF) mesoscale model were utilized to analyze the ABL characteristics over the PRD. Based on three types of weather condition simulations (i.e., subsidence days, rainy days, and sunny days), the WRF model revealed that the simulated temperature and wind fields in these three cases were moderately consistent with the measurements. The results showed that diurnal variations of the ABL height on subsidence days and sunny days were obvious, but diurnal variations of the ABL height on rainy days were not apparent. The ABL is obviously affected by local circulation, and the ABL features are different at various stations. A simulation focused on a high pollution episode during the subsidence days on 12-15 July 2006, occurred under high-pressure conditions, accompanied by the tropical cyclone "Bilis". A comparison of the simulated vertical wind fields and temperature
\end{abstract}

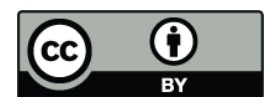

Correspondence to: Q. Fan (eesfq@mail.sysu.edu.cn) structure with the ABL measurements at Xinken, Panyu, and Qingyuan stations found that the modeled and measured atmospheric fields revealed two different types of ABL characteristics over the PRD. When the surface winds over the PRD were light or nearly calm, the local circulation dominated, such as the sea-land breeze at Xinken station and the mountain-valley circulation at Qingyuan station. When the surface winds were strong, the stations were under the same background weather system, and the wind directions were almost the same. Furthermore, the modeled results also suggest that the subsidence by the typhoon "Bilis" had a great impact on the high Air Pollution Index (API).

\section{Introduction}

The Pearl River Delta (PRD) in China is located in the middle of Guangdong province, which is one of the three largest Gross Domestic Product areas in China. It is a coastal, industrial area situated in a region of very complex wind regimes (Chen et al., 2009; Ding et al., 2004; Liu et al., 2002). The south of Guangdong province faces the South China Sea, with Nan Ling Mountain to the north and the PRD in the middle. The PRD is a rapidly growing area with more than 100 million people (Fig. 1a, b). It contains nine cities, including Guangzhou, Shenzhen, Foshan, Dongguan, Huizhou, Jiangmen, Zhongshan, Zhaoqing and Zhuhai, in addition to Hong Kong and Macao, called the PRD economic zone (PRDEZ). Several studies investigated the characteristics of the atmospheric boundary layer (ABL) over the PRD in the 1980s and 1990s (Huang and Liu, 1985; Guo, 1991; Liang et al., 1992), but in the past two decades, the PRD region has experienced a period of rapid economic development and

Published by Copernicus Publications on behalf of the European Geosciences Union. 


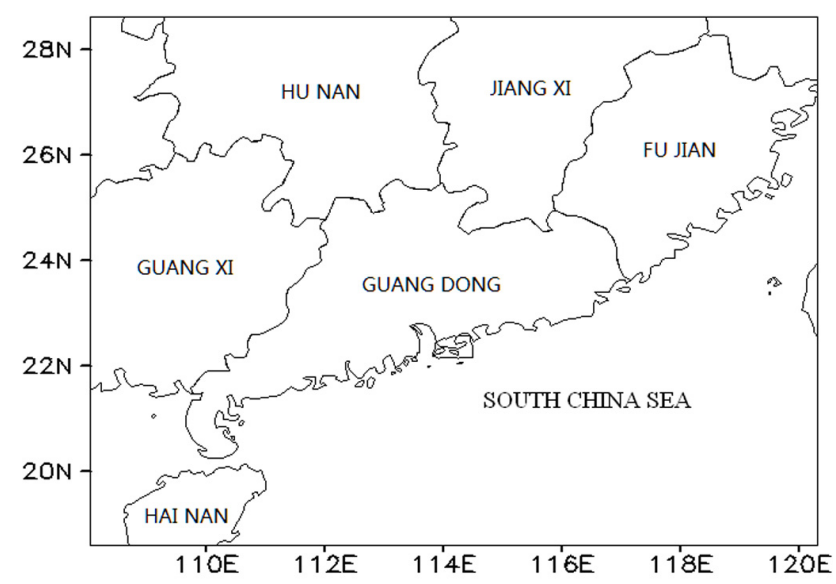

Fig. 1a. Map of Guangdong province and its surroundings.

urban expansion. Land use and land cover have dramatically changed (Wang et al., 2007). To reveal the meteorological and chemical characteristics of the PRD, the "Programme of Regional Integrated Experiments of Air Quality over the Pearl River Delta" (PRIDE-PRD) campaign of 2004 and 2006 was initiated. Much research has focused on these experimental results (Hua et al., 2008; Garland et al., 2008; Li et al., 2010; Lou et al., 2010; Yu et al., 2010; Verma et al., 2010; Miyazaki et al., 2009; Zhang et al, 2008a,b; Cheng et al., 2008a). Many studies found that the meteorological fields closely interacted with chemical composition, chemical reaction processes, and physical optical characteristics (Liu et al., 2008; Jung et al., 2009; Xiao et al., 2009; Lu et al., 2010; Zhang et al., 2008; Rose et al., 2010; Cheng et al., 2008b). The characteristics of wind, humidity, and thermodynamics are essential for analysing air quality problems.

The ABL measurements were a very important part of these two intensive campaigns. The characteristics of the ABL observations in Qingyuan, Panyu, and Xinken over the PRD in October 2004 were analyzed in a previous study (Fan et al., 2008). These observational results showed that a surface high-pressure system (anti-cyclone), descending motion outside of typhoons, and sea breezes result in high-level concentrations. The presence of anti-cyclone high-pressure systems and sea breezes led to the formation of three inversion layers, two aerosol layers, and specific vertical profiles of wind velocity over Xinken station. This study was based on the observations from three stations only. Limited by observational resolution, the results cannot present the detailed horizontal and vertical characteristics of the ABL over the PRD. Compared with the investigation by Fan et al. (2008), in addition to the analytical measurements, a numerical simulation of local circulation over the PRD was conducted. For this purpose, the Weather Research and Forecasting (WRF) model (http://www.wrf-model.org/index.php; Skamarock et al., 2007) was used to simulate atmospheric circulation on a regional scale.

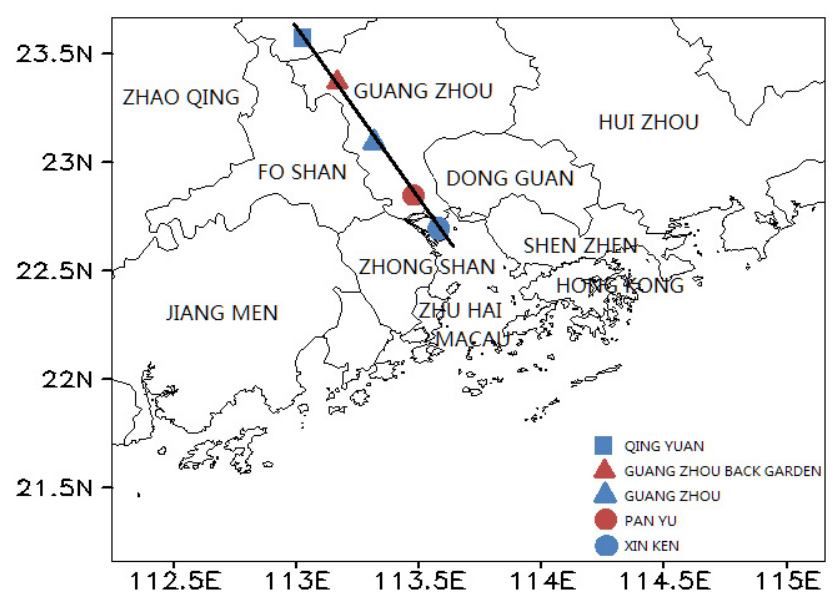

Fig. 1b. Map of PRD area. The measurement sites are shown.

The vertical structure and spatial and temporal variability of the ABL are very important for numerical weather prediction (NWP). Many studies have demonstrated that many meteorological characteristics of the ABL can be represented by the MM5 and WRF mesoscale models (Kwun et al., 2009; Zhu, 2008; Miao et al., 2009). Furthermore, an accurate depiction of the meteorological conditions within the ABL is also important for air pollution modeling. Knowledge of temperature, wind, the mixed layer height, turbulent kinetic energy (TKE), and horizontal and vertical circulation is essential for episodes of severe air pollution (Prtenjak et al., 2009; Hanna et al., 2010; Gilliam et al., 2010; Hu et al., 2010). The results from some model studies (Feng et al., 2007; Wu et al., 2005) showed that the most severe air pollution episodes over the PRD region were very often associated with subsidence by tropical cyclones or sea-land breezes. These studies (Feng et al., 2007; Wu et al., 2005) also showed that typhoons cause strong descending motion in the lower troposphere, weak surface winds, and a relatively low ABL. However, these studies were based on simulations provided by the MM5 or WRF model at a horizontal resolution of $12 \mathrm{~km}$. Thus, they did not offer detailed insights into fine-scale lower-tropospheric conditions, which we have accomplished in the present study. Another novelty of the present study is that we utilized WRF model results at $1 \times 1 \mathrm{~km}^{2}$ resolution. Many studies indicated that highresolution forecasts were keys for further progress in NWP model development (Mayer et al., 2010; Jury et al., 2009; Nolan et al., 2009a, b).

The present study investigated the detailed characteristics of the ABL over the PRD during the summer of 2006. We focused on three types of weather: (i) the tropical cyclone process, which occurred on 12-15 July 2006, and resulted in a high API pollution episode, (ii) the rainy days on 14-18 July 2006, and (iii) the sunny days on 2023 July 2006. The WRF model was utilized to investigate 


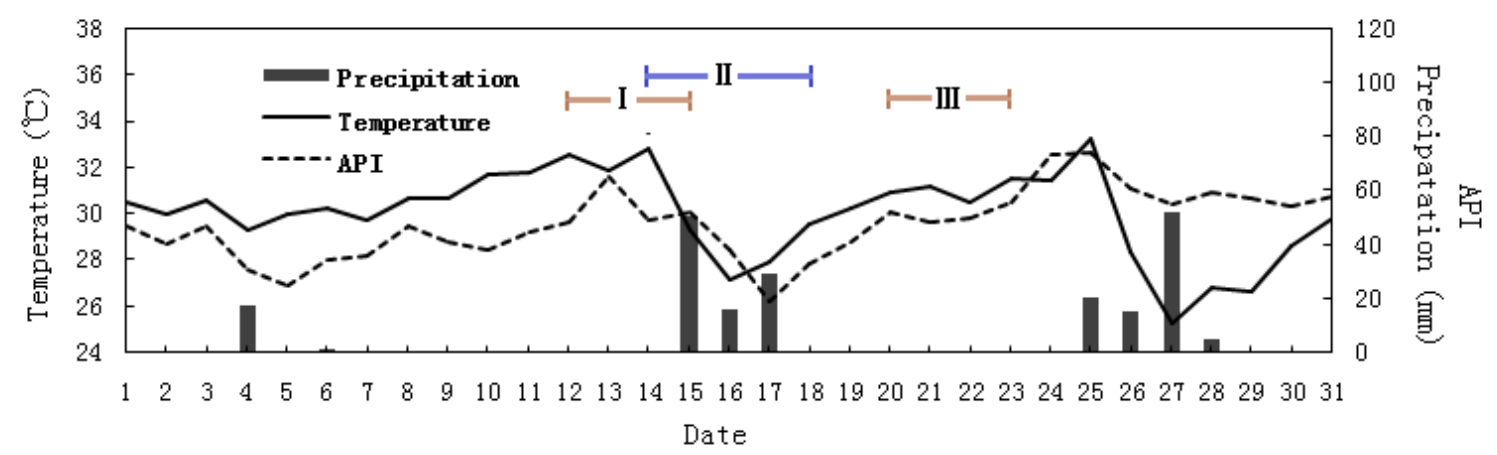

Fig. 2. The measured temperature, precipitation, and air pollution index (API) at Guangzhou station in July 2006 (period I: $12-15$ July; period II: 14-18 July; period III: 20-23 July).

the features of the ABL during these three periods. The simulation results were compared with the observations. In addition to various horizontal and vertical meteorological fields, local circulation was also analyzed. Section 2 below describes the field experiment setup and synoptic situations. The model settings and model results obtained from the three-dimensional numerical simulations are presented in Sect. 3. The conclusions are presented in Sect. 4.

\section{Experimental setup and synoptic situations}

\subsection{Experimental setup}

The selected PRD intensive campaign period occurred in the summer. During this period of the year, lower-pressure synoptic systems dominate, and the PRD region usually experiences pollution episodes attributable to the strong descending motion of typhoons (Feng et al., 2007; Wu et al., 2005). The campaign occurred on 1-30 July 2006.

To study the characteristics of the ABL over the PRD, five observational sites were selected (Fig. 1b): Qingyuan, Guangzhou Back Garden, Guangzhou, Panyu, and Xinken. Among these stations, Qingyuan, Panyu, and Xinken conducted sounding observations. Panyu station was located at the Panyu Meteorological Bureau $\left(22.56^{\circ} \mathrm{N}, 113.19^{\circ} \mathrm{E}\right)$, approximately $20 \mathrm{~km}$ south of central Guangzhou in the middle of the PRD. Qingyuan station was located at the Qingyuan Meteorological Bureau $\left(23.40^{\circ} \mathrm{N}, 113.03^{\circ} \mathrm{E}\right)$ in the north of the PRD. Xinken station was located in the town of Xinken $\left(22.37^{\circ} \mathrm{N}, 113.35^{\circ} \mathrm{E}\right)$ in the South of the PRD. Qingyuan and Xinken represent a more rural environment. At the Qingyuan station, vertical measurements were conducted with a meteorological radar. Mean wind speed and direction, temperature, and relative humidity were automatically derived from radio soundings. These parameters were reported several times per day between 0 and $3000 \mathrm{~m}$ with a vertical resolution of $100 \mathrm{~m}$. At the Panyu and Xinken stations, radio soundings were performed to obtain mean velocity, wind direction, and temperature. Radio soundings were launched seven times (06:00, 08:00, 10:00, 14:00, 18:00, 20:00, 23:00 LST) or eleven times (intensive observation, 02:00, 06:00, 07:00, 08:00, 10:00, 14:00, 17:00, 18:00, 19:00, 20:00, 23:00 LST) per day. Mean wind speed and direction were obtained at 0 and $2000 \mathrm{~m}$ with a vertical resolution of $50 \mathrm{~m}$. Mean temperature was reported with a vertical resolution of $10 \mathrm{~m}$.

The Guangzhou Back Garden and Guangzhou stations obtained hourly wind speed, wind direction, temperature, radiation, and relative humidity. The Guangzhou Back Garden station was located in the Guangzhou Back Garden $\left(23.55^{\circ} \mathrm{N}, 113.07^{\circ} \mathrm{E}\right)$, approximately $50 \mathrm{~km}$ north of central Guangzhou. Guangzhou station was located on the 16th floor (50 m above ground level) of the Guangdong Provincial Environmental Monitoring Center (GPEMC) building $\left(23.13^{\circ} \mathrm{N}, 113.26^{\circ} \mathrm{E}\right)$.

\subsection{Weather conditions in July 2006}

According to the Central Meteorological Station in Guangdong, the meteorological conditions over the PRD in July 2006 were characterized by high temperature and much precipitation. Figure 2 shows the measured temperature, precipitation, and API at Guangzhou station during July 2006, which had two periods of high temperatures on 12-14 and 23-25 July that corresponded to two strong tropical cyclones, Bilis and Kaemi, respectively. Two peaks in the API values were also influenced by these two tropical cyclone processes. Two strong precipitation processes occurred on 1517 and 26-30 July. On other sunny days, the entire PRD region was dominated by subtropical high pressure. In July 2006, the surface winds over the PRD were more controlled by the south, and the winds sometimes veered to the north from midnight until the morning in the northern areas. Vertical wind shear usually occurred at a height of $800 \mathrm{~m}$. The influence of sea-land breezes was obvious in the southern area of the PRD. This region is also often affected by tropical cyclones in the summer. Subsidence and precipitation from a tropical cyclone are vital to the air quality over the PRD. The wind speed in the ABL and ABL height decreases 
under subsidence, which results in an air pollution episode. The analysis of the sounding data in this experiment showed that when the background wind speed was small or calm, the wind fields at Panyu and Xinken stations changed dramatically with height, which was perhaps caused by local circulation, including heat island circulation and sea-land breezes. The wind profile at Panyu station was very complex with subsidence. Therefore, the present paper discusses three types of ABL features over the PRD. As shown in Fig. 2, period I includes the subsidence days on 12-15 July. Period II includes the rainy days on 15-18 July. Period III includes the sunny days on 20-22 July. As stated in the Introduction above, many studies (Feng et al., 2007; Wu et al., 2005) have already shown that strong descending motion can result in high-pollution weather over the PRD. The two API peaks during this month of July were also caused by subsidence motion from tropical cyclones. So we focused especially on the ABL characteristics over the PRD on 12-15 July. The detailed synoptic conditions during this period are discussed below.

Subtropical high pressure and subsidence caused by the tropical cyclone Bilis influenced the high temperatures over the PRD region on 12-14 July. The maximum temperature exceeded $32^{\circ} \mathrm{C}$ on these 3 days. Figure 3 shows the surface weather conditions on 12-15 July. The tropical cyclone Bilis originally formed from a tropical depression on 9 July 2006 over the western North Pacific. It intensified from a tropical storm to a severe tropical storm at 14:00 LST on 11 July. It made landfall at Yilan in Taiwan at midnight on 13 July and then tracked northwest. It then landed at Xiapu in the Fujian province at 12:00 LST on 14 July. The PRD region was west or southwest of Bilis during its movement.

\section{Model results}

\subsection{WRF model and settings}

To study the event, the WRF mesoscale model was employed. The WRF model consists of fully compressible nonhydrostatic equations on a staggered Arakawa $\mathrm{C}$ grid. Its vertical coordinate is a terrain-following hydrostatic pressure coordinate. The Runge-Kutta 3rd order time integration scheme, 5th order advection scheme in a horizontal direction, and 3rd order scheme in a vertical direction were used. A time-split small step for acoustic and gravity-wave modes was utilized. In the present study, four domains (Fig. 4), centered in the Pearl River Estuary, were configured on a horizontal grid of $139 \times 91,181 \times 148,322 \times 223$, and $367 \times 277$ points with resolutions of $27,9,3$, and $1 \mathrm{~km}$, respectively. The central latitude and longitude of the coarse domain (D01) were $23^{\circ} \mathrm{N}$ and $113^{\circ} \mathrm{E}$. Two-way nesting was applied for the domains. For the model to adequately resolve the boundary layer processes from the top to the surface level, 35 vertical sigma levels were used. Twenty layers were below a height of $2 \mathrm{~km}$. The finest topographical input was extracted from $30^{\prime \prime}$-resolution global terrain and land use files. The original USGS 24-category land cover data were employed.

The main physics options included Lin et al. microphysics, Betts-Miller-Janjic cumulus parameterization, the RRTM long-wave radiation scheme, the Goddard short-wave radiation scheme, and the MRF boundary layer scheme. For the two inner domains (D03 and D04), convection was assumed to be reasonably well resolved by the explicit microphysical parameterization scheme, and no cumulus parameterization scheme was used.

To represent the different ABL features, three types of weather were chosen. The first simulation period (period I) was from 00:00 UTC on 12 July 2006, to 00:00 UTC on 15 July 2006, representing the subsidence days. The second simulation (period II) was from 00:00 UTC on 14 July 2006, to 00:00 UTC on 18 July 2006 , representing the rainy days. The third simulation period (period III) was from 00:00 UTC on 20 July 2006, to 00:00 UTC on 23 July 2006, representing the sunny days. In all of these simulations, the lateral and initial conditions for the WRF simulations were obtained from NCEP/NCAR reanalysis daily $1^{\circ} \times 1^{\circ}$ grid data. In the present study, $12 \mathrm{~h}$ was used for the spinning up time.

To better understand the summer boundary layer characteristics of the PRD, the WRF mesoscale model was employed to study the detailed horizontal and vertical characteristics.

\subsection{Measured vs. modeled data}

To validate the WRF simulation results, the model results were compared with the available surface observations furnished by the main meteorological stations in domain 4 (Fig. 4). Table 1 shows some common statistical variables used to evaluate the performance of the model simulations, including the correlation coefficients $(R)$, mean bias (MB), mean absolute gross error (MAGE), root mean squared error (RMSE), and fractional absolute error (FAE). MB, MAGE, RMSE, and FAE are defined as the following (Yu et al., 2005):

$$
\begin{aligned}
& \mathrm{MB}=\frac{1}{\mathrm{MN}} \sum_{j=1}^{M} \sum_{k=1}^{N}\left(C_{j, k}^{m}-C_{j, k}^{o}\right) \\
& \mathrm{MAGE}=\frac{1}{\mathrm{MN}} \sum_{j=1}^{M} \sum_{k=1}^{N}\left|C_{j, k}^{m}-C_{j, k}^{o}\right| \\
& \mathrm{RMSE}=\frac{1}{M} \sum_{j=1}^{M}\left[\frac{1}{N} \sum_{k=1}^{N}\left(C_{j, k}^{m}-C_{j, k}^{o}\right)^{2}\right]^{1 / 2} \\
& \mathrm{FAE}=\frac{1}{\mathrm{MN}} \sum_{j=1}^{M} \sum_{k=1}^{N} \frac{\left|C_{j, k}^{m}-C_{j, k}^{o}\right|}{\left(C_{j, k}^{m}+C_{j, k}^{o}\right) / 2}
\end{aligned}
$$



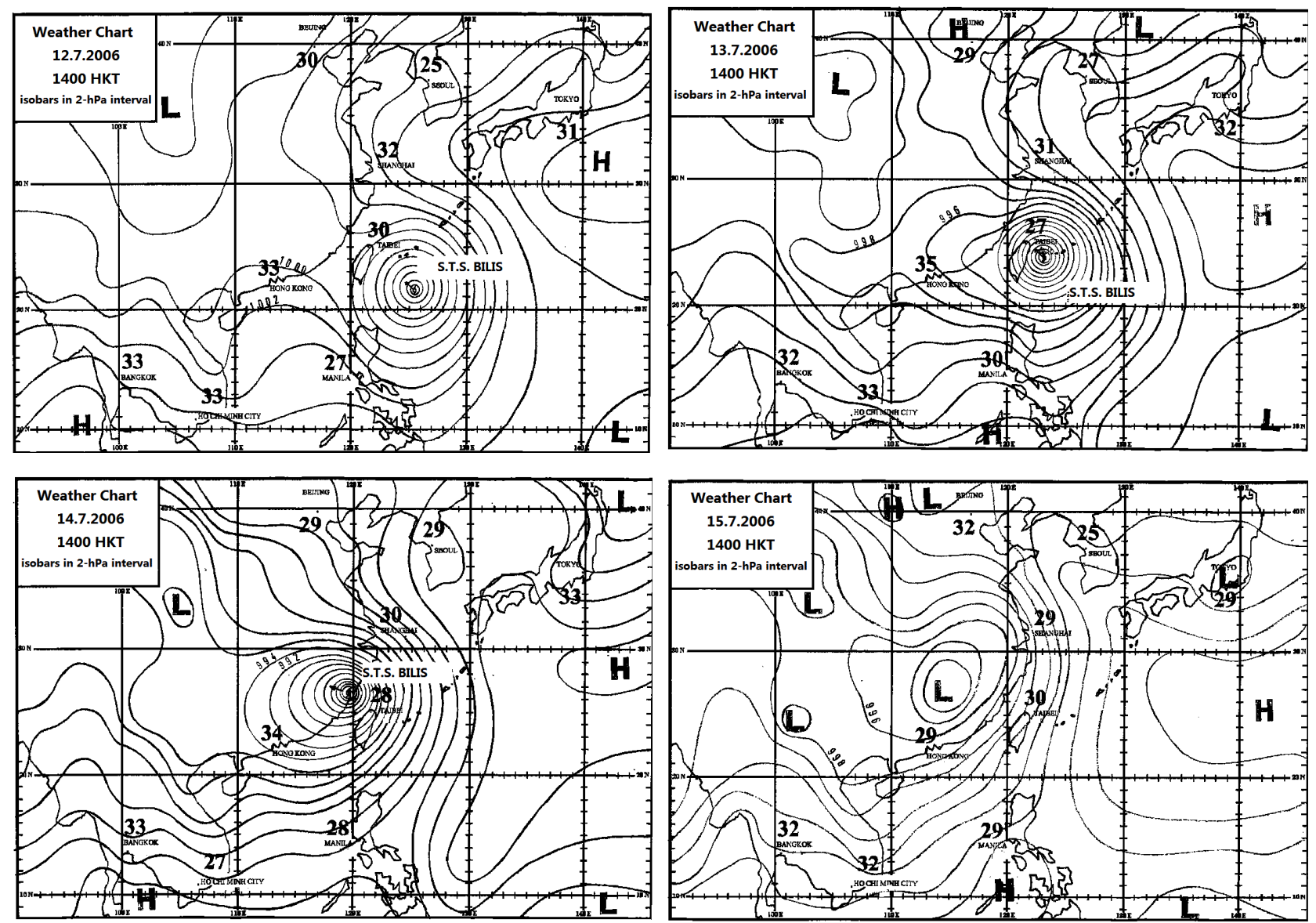

Fig. 3. Surface weather conditions on 12-15 July 2006.

Table 1. Statistical parameters between the measured $2 \mathrm{~m}$ air temperature ( $T$ ), wind speed (WS), and wind direction (WD) and the modeled WRF results on 12-15 July 2006 (period I), 15-18 July 2006 (period II), and 20-23 July 2006 (period III).

\begin{tabular}{|c|c|c|c|c|c|c|c|c|c|}
\hline & \multicolumn{3}{|c|}{ I } & \multicolumn{3}{|c|}{ II } & \multicolumn{3}{|c|}{ III } \\
\hline & WD & WS & $T$ & WD & WS & $T$ & WD & WS & $T$ \\
\hline Mean observable & 254.0 & 2.97 & 30.86 & 169.3 & 3.06 & 27.29 & 176.6 & 1.83 & 30.09 \\
\hline Mean simulation & 257.9 & 3.88 & 29.78 & 187.6 & 7.45 & 27.99 & 172.0 & 2.18 & 28.73 \\
\hline $\mathrm{R}$ & 0.46 & 0.42 & 0.72 & 0.45 & 0.39 & 0.49 & 0.61 & 0.43 & 0.93 \\
\hline MB & 3.92 & 0.91 & -1.08 & 18.33 & 4.39 & 0.70 & -4.57 & 0.35 & -1.26 \\
\hline MAGE & 36.34 & 1.78 & 1.80 & 39.02 & 4.47 & 1.29 & 52.88 & 0.99 & 1.31 \\
\hline RMSE & 51.07 & 2.19 & 2.19 & 47.39 & 4.96 & 1.53 & 69.92 & 1.22 & 1.63 \\
\hline FAE $(\%)$ & 4.1 & 14.0 & 1.5 & 6.0 & 21.9 & 1.2 & 8.7 & 14.7 & 1.2 \\
\hline
\end{tabular}

$M$ is the number of stations. $N$ is the number of numerical hours, excluding the spinning up time. $C^{m}$ and $C^{\circ}$ represent the modeled and observed values, respectively. From the definitions above, the more MB, MAGE, RMSE, and FAE approach zero, the better the model simulations are. In Table 1, with the exception of wind speed in period II, the average simulated wind direction, wind speed, and tem- perature during the three periods are all close to the observations. Good correlations were found between the simulated temperature and observations during periods I and III, with the correlation coefficient reaching 0.72 and 0.91 , respectively. The MB, MAGE, RMSE, and FAE values with respect to temperature were $-1.08,1.80,2.19^{\circ} \mathrm{C}$, and $1.5 \%$ during period $\mathrm{I}$ and $-1.26,1.31,1.63^{\circ} \mathrm{C}$, and $1.2 \%$ during 


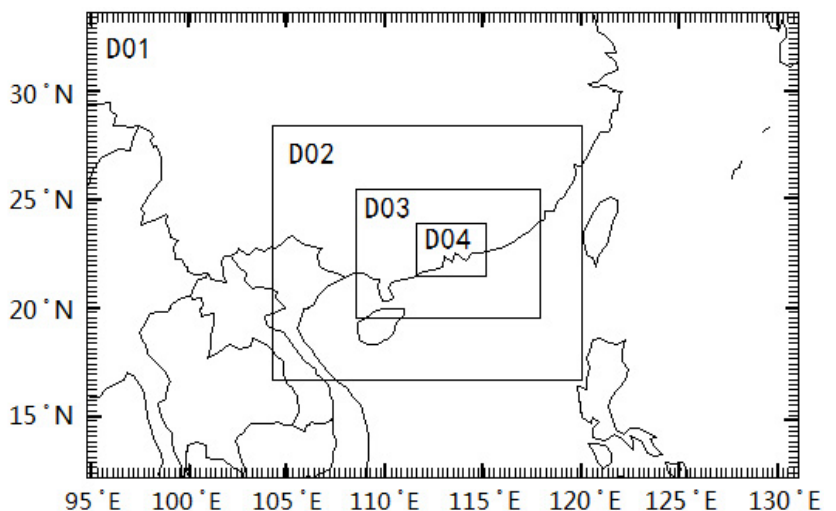

Fig. 4. Domain settings in WRF model.

period III, indicating good overall agreement between the observations and the simulations. For wind speed and wind directions during the three periods, the correlation coefficients were all approximately 0.4 , and the MB, MAGE, RMSE, and FAE values indicated that the model overestimated the wind fields most of the time. Notably, because the vector characteristics of the wind directions, MB, MAGE, RMSE, and FAE for wind directions were calculated by finding the actual differences in the angle between the modeled directions and observed directions. The simulated results during the subsidence days (period I) and sunny days (period III) were better than those during the rainy days (period II).

The time series of the hourly $2 \mathrm{~m}$ temperature, $10 \mathrm{~m}$ wind speed, and wind direction observed at Guangzhou station on 12-15 July (period I) and the corresponding simulations are shown in Fig. 5. The model generally performed well in the simulations of the diurnal variation tendency of air temperature. The increase in temperature on 14 July was captured well by the WRF model, but the model tended to underpredict temperature, especially on 12-13 July and 15 July. In the case of wind speed, the WRF simulations were in moderate agreement with the observations in terms of diurnal variations and magnitudes most of the time. Compared with the measurements, the simulated wind speeds were slightly lower on 13 July and slightly higher after the night of 14 July. Regarding wind direction, the observed and simulated winds were all from the west during the simulation period. The WRF model achieved good results, with the exception of noon on 13 July. At that time, the observed wind direction was northwest, but the simulated result was from the east. With the exception of that time, the wind direction results were satisfactory.
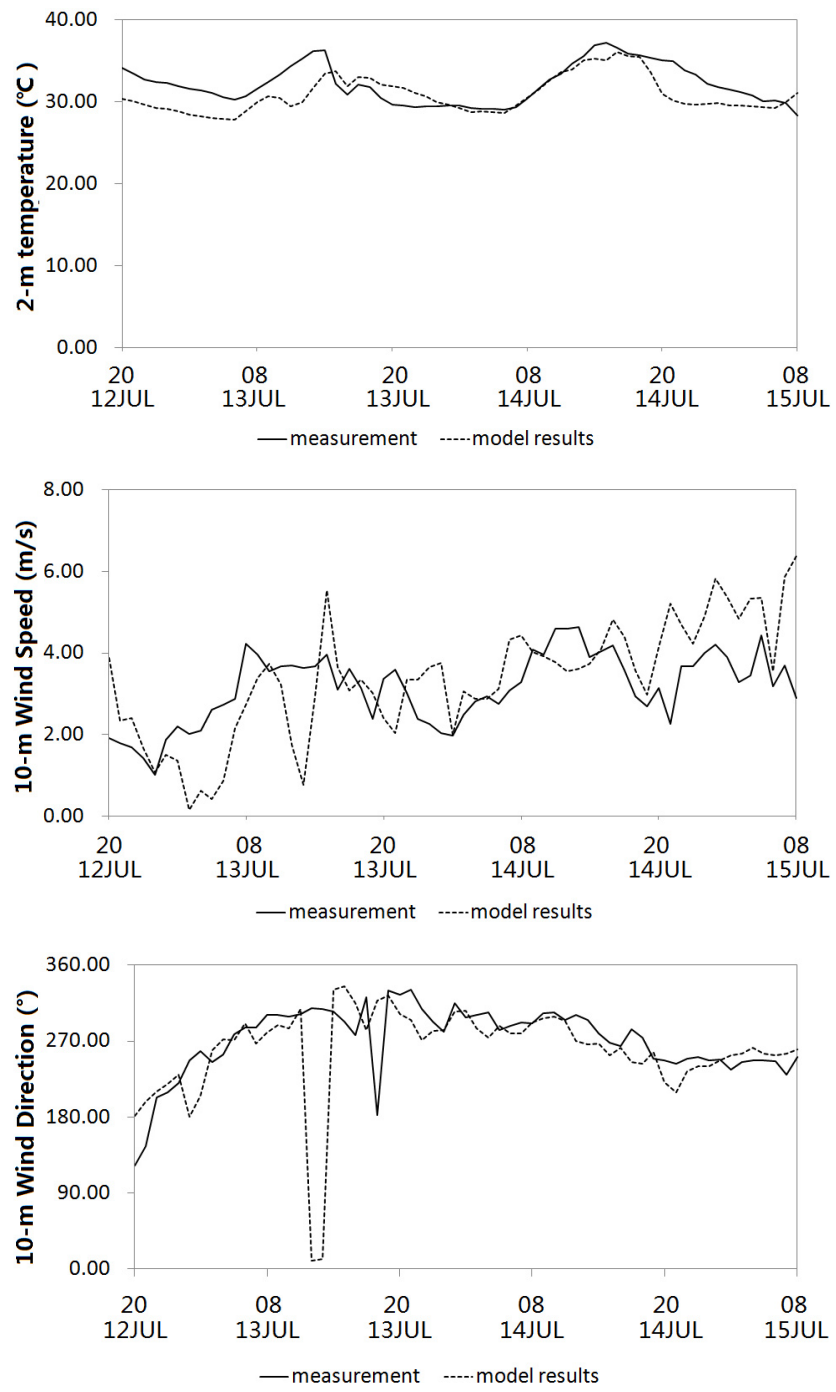

Fig. 5. Observed and simulated $2 \mathrm{~m}$ temperature, wind speed, and wind direction at Guangzhou station on 12-15 July 2006.

\subsubsection{Atmospheric boundary layer heights}

The ABL height is a critical parameter for vertical dispersion. An accurate assessment of boundary layer information on a finer scale should improve the ability to assess the pollutant diffusion process. The variation of the modeled WRF ABL height for the Qingyuan, Back Garden, Guangzhou, Panyu, and Xinken stations (Fig. 1b) during the three simulation periods and the Light Detection and Ranging (LIDAR) normalized relative backscattering signal observed at YuenLong station in Hong Kong are shown in Fig. 6.

At all five stations, the simulated diurnal variation of $\mathrm{ABL}$ height on the subsidence days and sunny days were all more obvious than on the rainy days. On the rainy days, the change in ABL height was instantaneous, and the ABL changed quickly from the stable regime to the convection regime. In contrast, on the subsidence days and sunny days, the ABL 

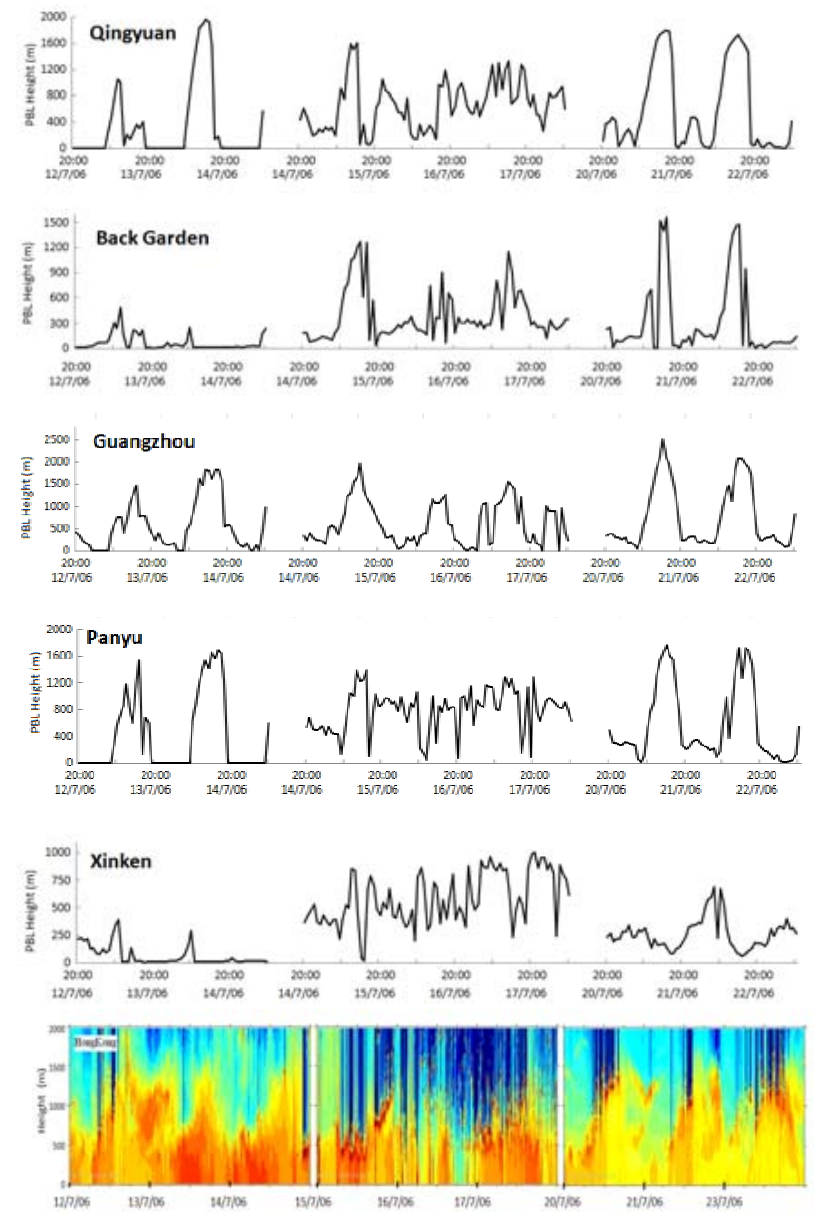

Fig. 6. Variation of the modeled WRF atmospheric boundary layer height (m) at the Qingyuan, Back Garden, Guangzhou, Panyu, and Xinken stations and the LIDAR normalized relative backscattering signal at Yuenlong station in Hong Kong.

was of a nocturnal regime at night and a free convection regime with strong heating from below. This can also be seen from the LIDAR normalized relative backscattering signal observed at YuenLong station in Hong Kong. These LIDAR measurements were obtained from Hong Kong University of Science and Technology. The LIDAR observations also showed obvious diurnal changes in ABL height on the subsidence days and sunny days. On the rainy days, diurnal variations were not apparent.

The daily evolutions and magnitude of ABL height at Xinken station were all different from the other four stations. The ABL heights during the three simulation periods at Xinken station were much lower than those at the other stations, and the diurnal variations in ABL height at Xinken station were also not clear. At the other four stations, the development of a well-mixed layer began at 08:0009:00 LST (e.g., 2-3 h after sunrise), reaching a maximum of $1500 \mathrm{~m}$ at approximately 14:00 LST. At night, the ABL was most stable, with heights lower than several hundred meters. Compared with these four stations, the daily evolutions of the ABL height at Xinken station were very special. For example, on the subsidence days, the daily maximum ABL height at Xinken station was approximately $400 \mathrm{~m}$ at 08:00 LST, which was much lower than those at the other stations. This time of occurrence was also earlier. Additionally, the ABL height at Xinken station from 09:00 LST on 13 July to 07:00 LST on 14 July remained very low. The ABL was statically stable, which was beneficial to the high pollution episode. From the wind profile measurements, the vertical wind direction and wind speed changed dramatically on these 2 days at Xinken station, which could have caused the ABL height at Xinken station to be lower than those at the other stations. The wind fields at Xinken station were complex because it is located in the Pearl River Estuary. In addition to the impact of the system wind, it is also affected by local circulation, such as sea-land breezes.

The simulated ABL heights during the nights of the subsidence days were much lower than those on other days. Influenced by the descending motion, the ABL was stable, and the ABL height decreased. The observations from the LIDAR signals showed that the maximum ABL height during the day reached approximately $1500 \mathrm{~m}$, and the ABL height during the nights of the subsidence days dropped to several hundred meters. The WRF model can capture the tendencies of diurnal variations in ABL height, and the simulated ABL heights during the day were moderately consistent with the LIDAR results. However, the heights at night were much lower than the measurements. At some stations, the simulated ABL heights were near zero. This was caused by the MRF high-resolution planetary boundary layer parameterization scheme used in the model. The ABL heights at night calculated by this scheme were much lower.

Figure 7 shows the measured air pollutant concentrations at Guangzhou station on 13-22 July. The comparison of the simulated ABL height results with the observed ambient concentrations shows that the temporal variations in ambient concentrations were closely related to the meteorological conditions. On 13-14 July, when the ABL height was high, the ambient concentrations were comparatively low under good diffusion conditions and vice versa. During this episode, the PRD area was under the influence of a subtropical high-pressure system and tropical cyclone Bilis. The combination of low ABL height, strong descending motion, and weak surface wind acted to keep the pollutants in the ABL, leading to comparatively high API values. During period II on 15-17 July, the ambient concentrations decreased because of the wet deposition by precipitation process. On the sunny days on 21-22 July, the ambient concentrations again appeared as obvious diurnal variations. A stable ABL and low ABL height resulted in high ambient concentrations. 


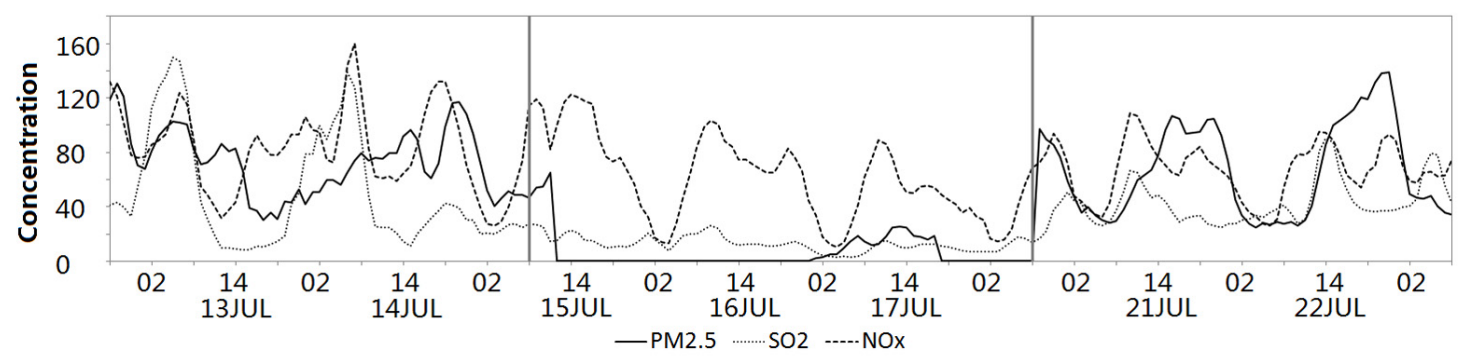

Fig. 7. Measured air pollutant concentrations at Guangzhou station on 13-22 July 2006 (units: $\mathrm{PM}_{2.5}, \mathrm{mg} \mathrm{m}^{-3} ; \mathrm{SO}_{2}, \mathrm{ppb}$, NO $\mathrm{x}_{\mathrm{x}}, \mathrm{ppb}_{\text {) }}$.

\subsubsection{Vertical wind and temperature distribution features}

The vertical radio sounding experiments were conducted at Panyu and Xinken stations in July 2006. Vertical measurements were made with a meteorological radar at Qingyuan station to explore the ABL features in different regions. For various reasons, the sounding data at these three stations during this month were inadequate. According to the actual corrected data during our three simulation periods, the vertical wind profile at Panyu station and vertical temperature profile at Qingyuan station on 14 and 21 July were analyzed.

The vertical wind profile measured at Panyu station and the simulated results using the WRF model on 14 and 21 July are shown in Fig. 8. The sounding measurements were cancelled on the rainy days, so the measurements on the subsidence days and sunny days were used for the comparisons. Obvious discrepancies were found in the vertical wind fields during the subsidence days and sunny days. The wind under the ABL at Panyu station was from the west all day on 14 July, with a low jet at a height of approximately $500 \mathrm{~m}$ at 06:00 LST. The wind was from the southwest near the surface and veered to the west at a very low height. The ABL height at that time was very low. The modeled ABL height in the WRF model was also very low (Fig. 6). At 16:00 LST and 17:00 LST, the wind in all of the ABLs changed to the southwest. The model results in Fig. 8b capture the ABL characteristics quite well, with the exception of the characteristics near the surface. The temporal resolution of the WRF model was higher than that of the measurements. The ABL features can be illustrated more clearly by the model results. The wind speed increased from 00:00 LST on 14 July reaching a maximum at approximately 07:00 LST. The maximum speed was located at a height of several hundred meters. The wind direction was nearly northwest, which corresponded to the measurements. After 10:00 LST, the wind speed began to decrease and was maintained for approximately $7 \mathrm{~h}$. At 17:00 LST, the wind speed increased again and veered to the southwest. Figure $8 \mathrm{c}$ shows that the wind profile was complex. In the morning of 21 July, the wind directions changed dramatically with height. Wind directions above $1000 \mathrm{~m}$ were mainly southeasterly and below $1000 \mathrm{~m}$ were southwesterly. At 14:00 LST, the wind in all of the ABLs was nearly from the south. After 16:00 LST, the wind veered to the southeast. The model results in Fig. 8d can reproduce the features of the measurements. At the beginning of 21 July, the wind in the low ABL was southwesterly and changed to southeasterly after 16:00 LST. At 06:00 LST, the southwest wind veered to the south at increasing heights. The minimum wind speed occurred at noon on 21 July. The wind speed increased after 16:00 LST, and the wind direction above $1000 \mathrm{~m}$ changed to the east at 23:00 LST. The wind profiles reproduced by the WRF model were generally satisfactory. On the subsidence days and sunny days, the wind profiles at Panyu station were all very complex. The wind speed and direction changed very fast, which was mainly caused by the local circulation.

Figure 9 shows the vertical temperature distribution measured by radar sounding and the results obtained by the model at Qingyuan station on 14 and 21 July. On 14 July, the WRF model captured the decrease of temperature with the height increase for three times, especially below $1000 \mathrm{~m}$. From 1000 to $3000 \mathrm{~m}$, the model overestimated the temperature about $1-2{ }^{\circ} \mathrm{C}$. At 07:00 LST on 21 July, the model results were consistent with the measurement. At 17:00 LST and 19:00 LST on 21 July the model also reproduced the measurement well below $1000 \mathrm{~m}$, however, above $1000 \mathrm{~m}$ the model underestimated the measurement. During these two periods, there was a slight inversion at $1500 \mathrm{~m}$ at Qingyuan station. The model shows that the temperature increased with the height increase at about $1500 \mathrm{~m}$, which is, however, lower than the actual value from the measurement.

\subsection{Horizontal wind fields on 12-14 July}

As stated in Sect. 3.2 above, the temperatures and wind fields simulated by the WRF model were moderately consistent with the measurements during the subsidence days, rainy days, and sunny days. Among these three types of weather, the subsidence days were the most important for the diffusion of air pollutants. The detailed horizontal wind fields and vertical circulation simulated by the WRF model during the subsidence days are analyzed below. 

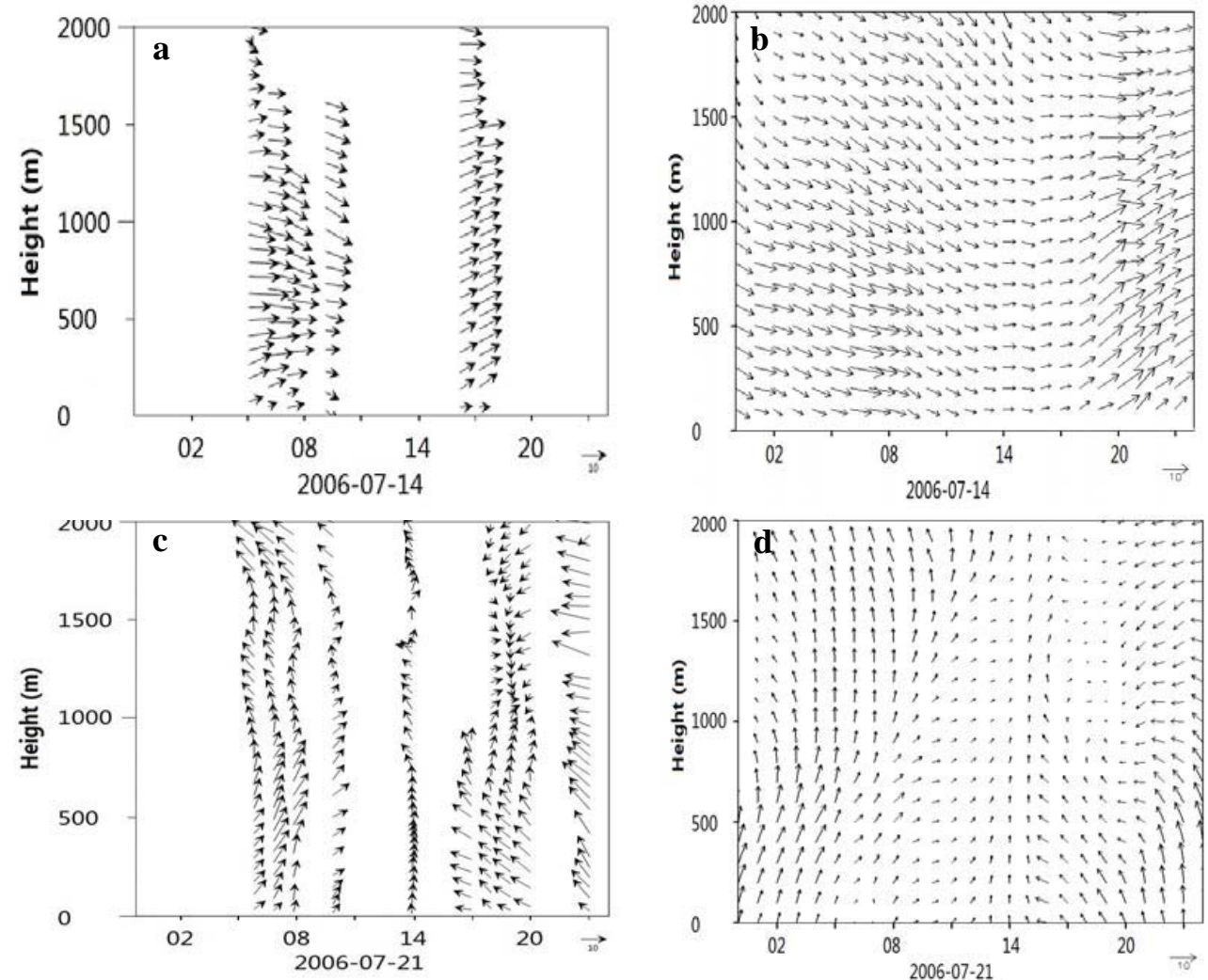

Fig. 8. Vertical wind profile by radio soundings at Panyu station on 14 July and 21 July 2006. (a) Observations on 14 July. (b) Simulations on 14 July. (c) Observations on 21 July. (d) Simulations on 21 July.
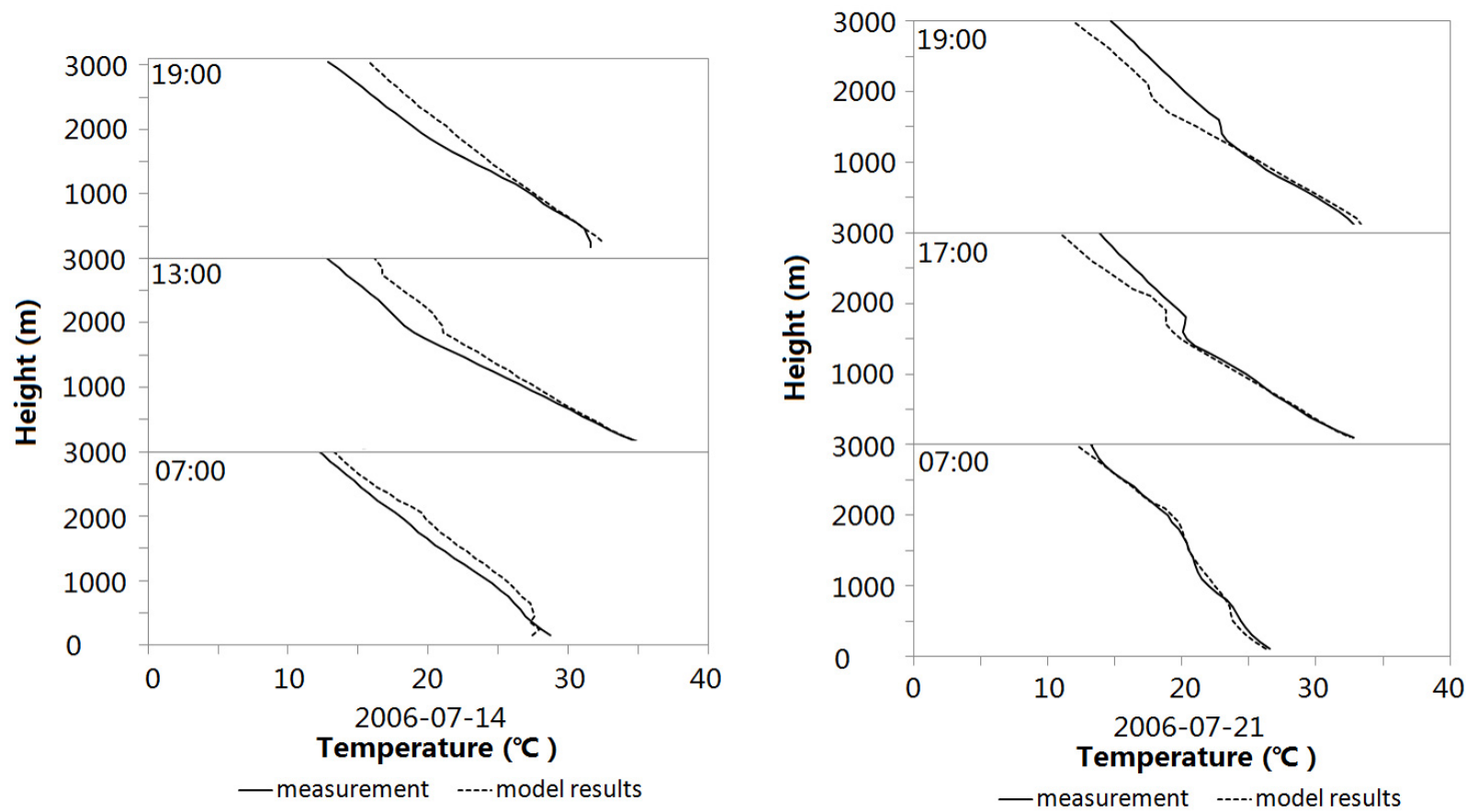

Fig. 9. Measured vertical temperature profile by radar soundings and the modeled results at Qingyuan station on 14 July and 21 July 2006. 

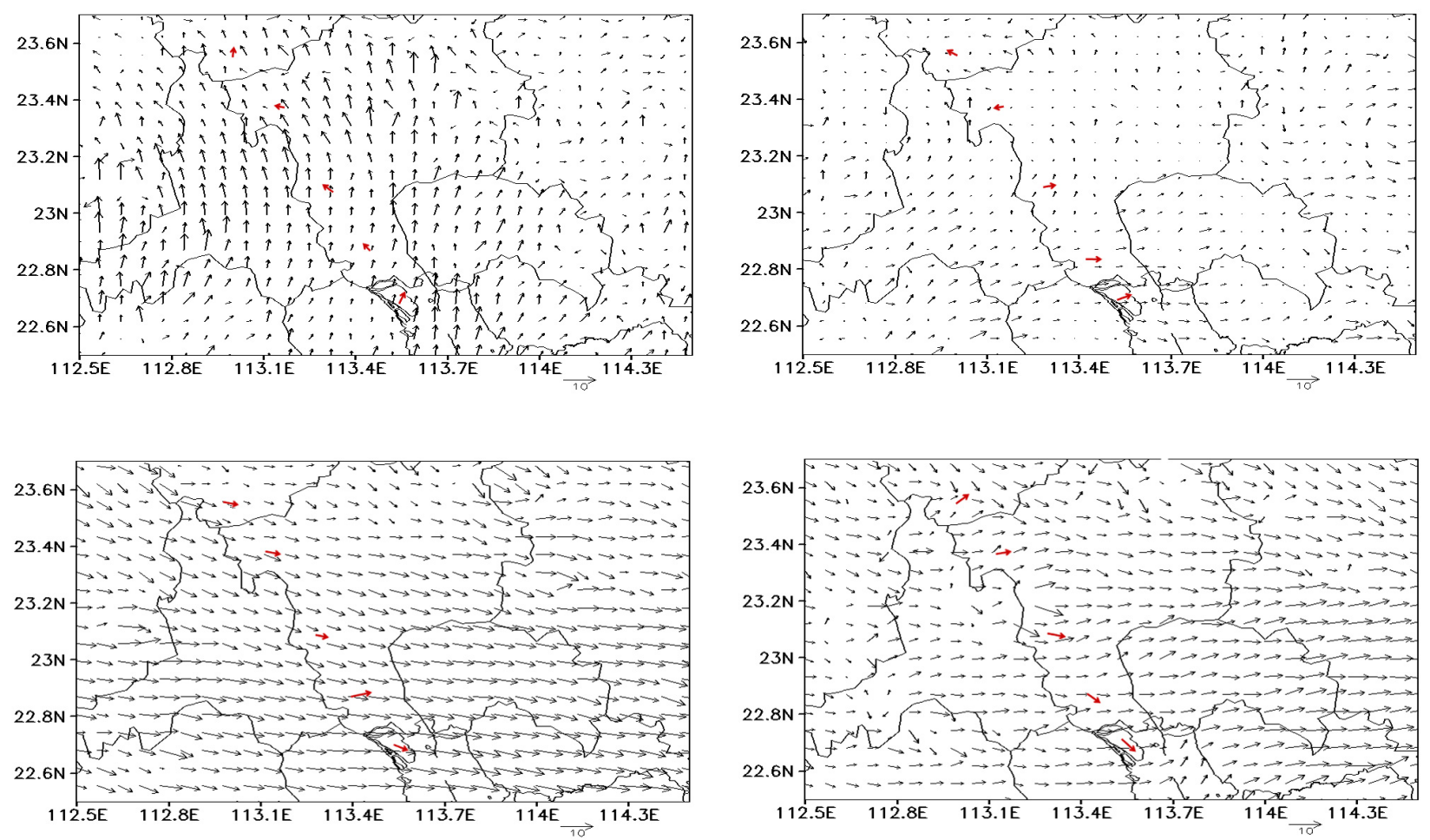

Fig. 10. Measured (red arrows) $10 \mathrm{~m}$ wind (ms-1) from the main meteorological stations in Fig. 1b and modeled WRF wind field (black arrows) over the PRD region. (a) 20:00 LST on 12 July. (b) 02:00 LST on 13 July. (c) 08:00 LST on 14 July. (d) 14:00 LST on 14 July.

Figure 10a and $\mathrm{b}$ show the observed and simulated $10 \mathrm{~m}$ wind vectors over the PRD region at 20:00 LST on 12 July and at 02:00 LST on 13 July. These clearly show that different local circulations dominated the PRD region, and the wind vectors varied at different stations. Figure 10a shows that at Xinken station, which is located in the Pearl River Estuary, the winds were from the south. The wind was obviously influenced by the sea breezes. At Panyu station, approximately $20 \mathrm{~km}$ south of central Guangzhou, the wind direction was southeast and the wind speed decreased. At Guangzhou station in the urban center, the wind veered toward the east and the wind speed increased. At Guangzhou Back Garden station, the wind speed decreased again. At Qingyuan station, the wind changed to the south. The simulated wind fields were almost consistent with the observations. The wind speeds at Xinken and Guangzhou stations were larger than at the other stations. At 02:00 LST on 13 July (Fig. 10b), the wind speeds were less than those at 20:00 LST on 12 July (Fig. 10a), and local circulation was also very apparent. The winds at Xinken station changed to the west, which was also affected by sea-land breezes. At the Panyu and Guangzhou stations, the wind directions were still from the west, but the wind speeds decreased. At Guangzhou Back Garden station, the winds veered to the east, and at Qingyuan station, the winds changed to the southeast. These two stations were influenced by local circulation, which was different from the other three stations. At that time, the tropical cyclone Bilis still had not made landfall, and the location of Bilis was far from the PRD region. The average wind speed in Guangzhou on 12 July was $1.54 \mathrm{~m} \mathrm{~s}^{-1}$. Under the small background system wind fields, local circulation was essential for the various stations. Figure $10 \mathrm{c}$ and $\mathrm{d}$ show the observed and simulated wind vectors over the PRD region at 08:00 LST on 14 July and at 14:00 LST on 14 July. In contrast to Fig. 10a and b, the wind fields at the various stations seemed very similar. In Fig. 10c, the aforementioned stations were all controlled by westerly winds. At that time, the tropical cyclone Bilis had made landfall, and the PRD regions were deeply influenced by Bilis. The average wind speed in Guangzhou on 14 July was $3.46 \mathrm{~m} \mathrm{~s}^{-1}$. The winds at the various stations over the PRD tended to be less under such background system wind fields. The winds in Fig. 10d were almost northwest. The wind direction at Qingyuan station was southwest because it is located to the south of the Nanling Mountain areas and is influenced by the downstream flow from the slopes of the high mountains. 

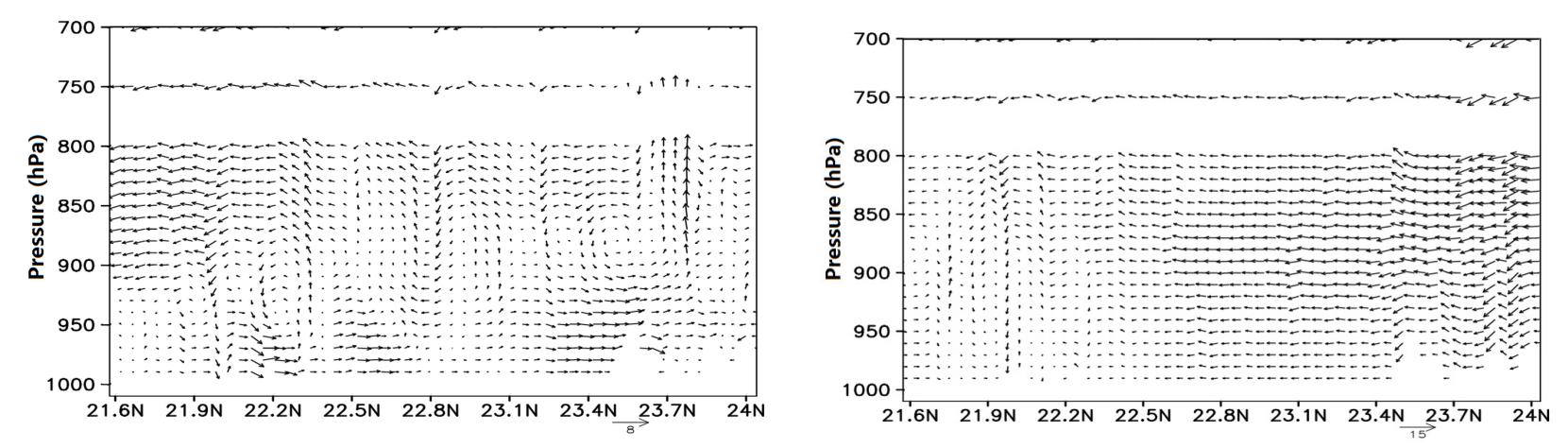

Fig. 11. Vertical cross-sections of WRF modeled wind $\left(\mathrm{m} \mathrm{s}^{-1}\right)$ along 113.2 $\mathrm{E}(\mathbf{a})$ at 03:00 LST on 13 July and (b) at 03:00 LST on 14 July.

\subsection{Vertical circulation on 12-14 July}

The modeled vertical cross-sections of the wind vectors along $113.2^{\circ} \mathrm{E}$ at 03:00 LST on 13 July and at 03:00 LST on 14 July are presented in Fig. 11. The analysis concentrated on local circulation. At 03:00 LST on 13 July (Fig. 11a), different wind fields were noted near the coast compared with adjacent urban cities. As mentioned above, when the system wind speed was small, the local circulation was essential for the various stations. During this episode, the tropical cyclone Bilis made landfall at midnight on 13 July. The influence of Bilis was not very apparent over the PRD region at 03:00 LST on 13 July. Figure 11a shows that the coastal areas (such as the Pearl River Estuary at approximately $22.2^{\circ} \mathrm{N}$ ) were dominated by the south. The surface layer was under the influence of the incoming sea breeze. The air converged and ascended in the coastal region, and the wind direction veered toward the north at $900 \mathrm{hPa}$, with obvious sealand breeze circulation. The wind fields were influenced by urban heat island circulation at Panyu and Guangzhou stations. The heat island circulation was comparatively complex. The ascending and descending motion was weak, and the horizontal south (near the surface) and north wind fields (approximately $850 \mathrm{hPa}$ ) were apparent. Compared with the coastal areas, the urban regions were under the control of divergence and resulted in a stable and low ABL. The wind direction at Qingyuan station (approximately $23.4^{\circ} \mathrm{N}$ ) was also south, but with ascending motion in the high vertical latitude. Another circulation appeared to affect the wind fields in Qingyuan. In the North of Qingyuan is Nanling Mountain (approximately $25^{\circ} \mathrm{N}$ ), and the flow from the south encounters the mountains and uplifts, then veers to the north at high latitude and descends. Qingyuan is always affected by the mountain-valley wind from the slopes of the high mountains. Overall, when the system wind is weak, three types of local circulations occur-sea-land breeze, urban heat island, and mountain-valley wind-over the PRD region. These local circulations make the ABL characteristics over the PRD unique.
When the system wind was moderate, the wind fields over the PRD region tended to be similar. At 03:00 LST on 14 July (Fig. 11b), the tropical cyclone Bilis had already made landfall and decreased in intensity. The PRD region was located southwest of the cyclone. The entire PRD region was controlled by the north wind in the low troposphere, with nearly negligible discrepancies between the different stations.

\section{Conclusions}

The ABL characteristics at different sites over the PRD were analyzed by measurements and model results from the WRF mesoscale model during three types of weather, with a focus on a comparatively high API episode on 12-15 July 2006. The results showed that the ABL characteristics at the different stations varied. These local-scale meteorological conditions could not be captured by $50 \mathrm{~km}$ and $10 \mathrm{~km}$ resolution meteorological models. Fine-scale (i.e., $1 \mathrm{~km}$ resolution) meteorological (WRF) results demonstrated a successful simulation of the ABL and reasonable agreement with the available observations. The main meteorological results provided by the present study can be used for other PRD July intensive campaign studies. The meteorological model results can be further used in air quality models to perform air concentration simulations. The temporal variation tendencies of various air pollutant concentrations can also be interpreted by detailed ABL features. The main conclusions of the present study are summarized below.

- The ABL features associated with three types of weather (i.e., subsidence days, rainy days, and sunny days) in July 2006 were analyzed using observations and WRF model simulations. The results showed that the model could reproduce the meteorological fields moderate well. The ABL evolution on the rainy days was different from the ABL evolution on subsidence days and sunny days. Diurnal variations in ABL height on rainy days were not apparent. 
- The evolution of the ABL height at the Guangzhou, Panyu, Back Garden, and Qingyuan stations were similar, and the diurnal variation process was obvious. During the day, the ABL was convective, and the maximum ABL height reached approximately $1500 \mathrm{~m}$. During the night, the ABL became stable, and the ABL height substantially decreased to just several hundred meters. At Xinken station, the ABL height was comparatively lower than at the other stations. The wind direction and wind speed also changed dramatically compared with the observations.

- Compared with the other days in July 2006, the temperature and API values were higher on 12-15 July. The stable and low ABL, descending motion, and weak horizontal wind did not benefit the diffusion of air pollutants and resulted in high air concentrations.

- The detailed analyses of the wind regimes and thermodynamic structures of the lower troposphere over the PRD showed an obvious discrepancy between the different sites under small background wind conditions. The differences were induced by local effects over the PRD areas, such as sea-land breezes, urban heat islands, and mountain-valley winds. When the system background wind speed was moderate, the differences between the various sites were not apparent, and the wind fields tended to be similar.

- The ABL characteristics are important for identifying the air pollution problem. The ABL features are very complex over the PRD region, especially in weak or calm winds, which are always accompanied by high pollutant concentrations. However, the episode described in the present paper was characterized by an extremely complex ABL, accompanied by subsidence by the tropical cyclone Bilis. Thus, simultaneous local circulations were responsible for the different wind fields at various sites. Finally, the local meteorological conditions were favorable for the formation of a stable ABL and air pollution episode.

Acknowledgements. This study was supported by funds from China National Basic Research and Development Programs 2002CB410801 and 2002CB211605 and National Natural Science Foundation 40805043, 40875007, and 90715031. The authors would like to acknowledge the science team of the PRD July intensive campaign for their successful collaboration. The authors thank the Guangdong Meteorological Bureau, particularly Y. R. Feng, for providing the meteorological observations and various anonymous reviewers for providing suggestions.

Edited by: S. C. Liu

\section{References}

Chen, X. L., Feng, Y. R., Li, J. N., Lin, W. S., Fan, S. J., Wang, A. Y., Fong, S. K., and Lin, H.: Numerical simulation on the effect of sea-land breezes on atmospheric haze over the Pearl River Delta region, Environ. Model. Assess., 14, 351-363, 2009.

Cheng, Y. F., Wiedensohler, A., Eichler, H., Su, H., Gnauk, T., Brüggemann, E., Herrmann, H., Heintzenberg, J., Slanina, J., Tuch, T., Hu, M., and Zhang, Y. H.: Aerosol optical properties and related chemical apportionment at Xinken in Pearl River Delta of China, Atmos. Environ., 42, 6351-6372, 2008a.

Cheng, Y. F., Wiedensohler, A., Eichler, H., Heintzenberg, J., Tesche, M., Ansmann, A., Wendisch, M., Su, H., Althausen, D., Herrmann, H., Gnauk, T., Brüggemann, E., Hu, M., and Zhang, Y. H.: Relative humidity dependence of aerosol optical properties and direct radiative forcing in the surface boundary layer at Xinken in Pearl River Delta of China: an observation based numerical study, Atmos. Environ., 42, 6373-6397, 2008 b.

Ding, A. J., Wang, T., Zhao, M., Wang, T. J., and Li, Z. K.: Simulation of sea-land breeze and a discussion of their implication on the transport of air pollution during a multi-day ozone episode in the Pearl River Delta of China, Atmos. Environ., 38, 6737-6750, 2004.

Fan, S. J., Wang, B. M., Tesche, M., Engelmann, R., Althausen, A., Liu, J., Zhu, W., Fan, Q., Li, M. H., Ta, N., Song, L. L., and Leong, K. C.: Meteorological conditions and structures of atmospheric boundary layer in October 2004 over Pearl River Delta area, Atmos. Environ., 42, 6174-6186, 2008.

Feng, Y. R., Wang, A. Y., Wu, D., and Xu, X. D.: The influence of tropical cyclone Melor on PM10 concentrations during an aerosol episode over the Pearl River Delta region of China: Numerical modelling versus observational analysis, Atmos. Environ., 41, 4349-4365, 2007.

Garland, R. M., Yang, H., Schmid, O., Rose, D., Nowak, A., Achtert, P., Wiedensohler, A., Takegawa, N., Kita, K., Miyazaki, Y., Kondo, Y., Hu, M., Shao, M., Zeng, L. M., Zhang, Y. H., Andreae, M. O., and Pöschl, U.: Aerosol optical properties in a rural environment near the mega-city Guangzhou, China: implications for regional air pollution, radiative forcing and remote sensing, Atmos. Chem. Phys., 8, 5161-5186, doi:10.5194/acp-85161-2008, 2008.

Gilliam, C. R. and Pleim, E. J.: Performance Assessment of New Land Surface and Planetary Boundary Layer Physics in the WRF-ARW, J. Appl. Meteorol. Clim., 49, 760-774, 2010.

Guo, D. Z.: A study of the characteristics in the coastal boundary layer in the low latitude, Res. Environ. Sci., 5, 34-39, 1991 (in Chinese).

Hanna, R. S., Reen, B., Hendrick, E., Santos, L., Stauffer, D., Deng, A. J., and McQueen, J.: Comparison of observed, MM5 and WRF-NMM model-simulated, and HPAC-assumed boundarylayer meteorological variables for 3 days during the IHOP field experiment, Bound.- Lay. Meteorol., 134, 285-306, 2010.

Hu, X. M., Nielsen-Gammon, W. J., and Zhang, F. Q.: Evaluation of three planetary boundary layer schemes in the WRF model, J. Appl. Meteorol. Clim., e-View, 2010.

Hua, W., Chen, Z. M., Jie, C. Y., Kondo, Y., Hofzumahaus, A., Takegawa, N., Chang, C. C., Lu, K. D., Miyazaki, Y., Kita, K., Wang, H. L., Zhang, Y. H., and Hu, M.: Atmospheric hydrogen peroxide and organic hydroperoxides during PRIDEPRD'06, China: their concentration, formation mechanism and 
contribution to secondary aerosols, Atmos. Chem. Phys., 8, 6755-6773, doi:10.5194/acp-8-6755-2008, 2008.

Huang, Z. X. and Liu, J. L.: A preliminary results of observation on sea-land breezes in Lingding Yang area, Journal of Tropical Oceanography, 3, 21-29, 1985 (in Chinese).

Kwun, J. H., Kim, Y. K., Seo, J. W., Jeong, J. H., and Sung, H. Y.: Sensitivity of MM5 and WRF mesoscale model predictions of surface winds in a typhoon to planetary boundary layer parameterizations, Nat. Hazards, 51, 63-77, 2009.

Jung, J. S., Lee, H. L., Kim, Y. J., Liu, X. G., Zhang, Y. H., Gu, J. W., and Fan, S. J.: Aerosol chemistry and the effect of aerosol water content on visibility impairment and radiative forcingin Guangzhou during the 2006 Pearl River Delta campaign, J. Environ. Manag., 90, 3231-3244, 2009.

Jury, R. M., Chiao, S., and Harmsen, E. W.: Mesoscale Structure of Trade Wind Convection over Puerto Rico: Composite Observations and Numerical Simulation, Bound.-Lay. Meteorol., 132, 289-313, 2009.

Li, X., Brauers, T., Shao, M., Garland, R. M., Wagner, T., Deutschmann, T., and Wahner, A.: MAX-DOAS measurements in southern China: retrieval of aerosol extinctions and validation using ground-based in-situ data, Atmos. Chem. Phys., 10, 20792089, doi:10.5194/acp-10-2079-2010, 2010.

Liang, H. M., Dong, B. Q., and Tian, G. S.: The characteristics analysis of the stratification in the ambient air over Pearl River Delta area, Res. Environ. Sci., 4, 8-14, 1992 (in Chinese).

Liu, H. P. and Chan, J. C. L.: An investigation of air-pollution patterns under sea-land breezes during a server air-pollution episode in Hong Kong, Atmos. Environ., 36, 591-601, 2002.

Liu, X. G., Cheng, Y. F., Zhang, Y. H., Jung, J. S., Sugimoto, N., Chang, S. Y., Kim, Y. J., Fan, S. J., and Zeng, L. M.: Influences of relative humidity and particle chemical composition on aerosol scattering properties during the 2006 PRD campaign, Atmos. Environ., 42, 1525-1536, 2008.

Lou, S., Holland, F., Rohrer, F., Lu, K., Bohn, B., Brauers, T., Chang, C. C., Fuchs, H., Häseler, R., Kita, K., Kondo, Y., Li, X., Shao, M., Zeng, L., Wahner, A., Zhang, Y., Wang, W., and Hofzumahaus, A.: Atmospheric $\mathrm{OH}$ reactivities in the Pearl River Delta - China in summer 2006: measurement and model results, Atmos. Chem. Phys., 10, 11243-11260, doi:10.5194/acp-10-11243-2010, 2010.

Lu, K. D., Zhang, Y. H., Su, H., Shao, M., Zeng, L. M., Zhong, L. J., Xiang, Y. R., Chang, C. C., Chou, C. K. C., and Wahner, A.: Regional ozone pollution and key controlling factors of photochemical ozone production in Pearl River Delta during summer time, Science China (Chemistry), 53, 651-663, 2010.

Mayer, S., Sandvik, A., Jonassen, O. M., and Reuder, J.: Atmospheric profiling with the UAS SUMO: a new perspectivefor the evaluation of fine-scale atmospheric models, Meteorol. Atmos. Phys., doi:10.1007/s00703-010-0063-2, 2010.

Miyazaki, Y., Kondo, Y., Shiraiwa, M., Takegawa, N., Miyakawa, T., Han, S., Kita, K., Hu, M., Deng, Z. Q., Zhao, Y., Sugimoto, N., Blake, D. R., and Weber, R. J.: Chemical characterization of water-soluble organic carbon aerosols at a rural site in the Pearl River Delta, China, in the summer of 2006, J. Geophys. Res.Atmos., 114, D14208, doi:10.1029/2009JD011736, 2009.

Miao, S. G., Chen, F., Margaret, A., LeMone, Tewari, M., Li, Q. C., and Wang, Y. C.: An Ob- servational and Modeling Study of Characteristics of Urban Heat Island and Boundary Layer Struc- tures in Beijing, J. Appl. Meteorol. Clim., 48, 484-501, 2009.

Nolan, S. D., Zhang, A. J., and Stern, P. D.: Evaluation of planetary boundary layer param- eterizations in tropical cyclones by comparison of in situ observations and high-resolution simulations of hurricane Isabel (2003) - Part I: Initialization, maximum winds, and the outer- core boundary layer, Mon. Weather Rev., 137, 3651-3674, 2009a.

Nolan, S. D., Zhang, A. J., and Stern, P. D.: Evaluation of planetary boundary layer parameterizations in tropical cyclones by comparison of in situ observations and high-resolution simulations of hurricane Isabel (2003) - Part II: Inner-core boundary layer and eyewall structure, Mon. Weather Rev., 137, 3675-3698, $2009 \mathrm{~b}$.

Prtenjak, M. T., Jeričević, A., Kraljević, L., Bulić, I. H., Nitis, T., and Klaić, Z. B.: Exploring atmospheric boundary layer characteristics in a severe SO2 episode in the north-eastern Adriatic, Atmos. Chem. Phys., 9, 4467-4483, doi:10.5194/acp-9-4467-2009, 2009.

Rose, D., Nowak, A., Achtert, P., Wiedensohler, A., Hu, M., Shao, M., Zhang, Y., Andreae, M. O., and Pöschl, U.: Cloud condensation nuclei in polluted air and biomass burning smoke near the mega-city Guangzhou, China - Part 1: Size-resolved measurements and implications for the modelling of aerosol particle hygroscopicity and CCN activity, Atmos. Chem. Phys., 10, 33653383, doi:10.5194/acp-10-3365-2010, 2010.

Skamarock, W. C., Klemp, J. B., Dudhia, J., Gill, D. O., Barker, D. M., Wang, W., and Powers, J. G.: A description of the Advanced Research WRF Version 2, NCAR/TN-468+STR, Ncar Technical Note, 88 pp., available at: http://www.mmm.ucar.edu/wrf/users/ docs/arw_v2.pdf, January 2007.

Verma, R. L., Sahu, L. K., Kondo, Y., Takegawa, N., Han, S., Jung, J. S., Kim, Y. J., Fan, S., Sugimoto, N., Shammaa, M. H., Zhang, Y. H., and Zhao, Y.: Temporal variations of black carbon in Guangzhou, China, in summer 2006, Atmos. Chem. Phys., 10, 6471-6485, doi:10.5194/acp-10-6471-2010, 2010.

Wang, X. M., Lin, W. S., Yang, L. M., Deng, R. R., and Lin, H., A numerical study of influences of urban land-use change on ozone distribution over the Pearl River Delta region, China. Tellus B, 59B, 633-641, 2007.

Wu, D., Tie, X. X., Li, C. C., Ying, Z. M., Lau, A. K. H., Huang, J., Deng, X. J., and Bi, X. Y.: An extremely low visibility event over the Guangzhou region: a case study, Atmos. Environ., 39, 6568-6577, 2005.

Xiao, R., Takegawa, N., Kondo, Y., Miyazaki, Y., Miyakawa, T., Hu, M., Shao, M., Zeng, L. M.,Hofzumahaus, A., Holland, F., Lu, K., Sugimoto, N., Zhao, Y., and Zhang, Y. H.: Formation of submicron sulfate and organic aerosols in the outflow from the urban region of the Pearl River Delta in China, Atmos. Environ., 43, 3754-3763, 2009.

Yu, H., Wu, C., Wu, D., and Yu, J. Z.: Size distributions of elemental carbon and its contribution to light extinction in urban and rural locations in the Pearl River delta region, China, Atmos. Chem. Phys., 10, 5107-5119, doi:10.5194/acp-10-5107-2010, 2010.

Yu, S., Eder, B., Dennis, R., Chu, S. H., and Schwariz, S.: On the development of new metrics for the evaluation of air quality models, Atmos. Sci. Lett., 7, 26-34, 2005.

Zhang, Y. H., Su, H., Zhong, L. J., Cheng, Y. F., Zeng, L. M., Wang, X. S., Xiang, Y. R., Wang, J. L., Gao, D. F., Shao, M., Fan, S. J., and Liu, S. C.: Regional ozone pollution and observation-based approach for analyzing ozone-precursor relationship during the 
PRIDE- PRD2004 campaign, Atmos. Environ., 42, 6203-6218, 2008a.

Zhang, Y. H., Hu, M., Zhong, L. J., Wiedensohlerg, A., Liu, S. C., Andreae, M. O., Wang, W., and Fan S. J.: Regional integrated experiments on air quality over Pearl River Delta 2004(PRIDEPRD2004): overview, Atmos. Environ., 42, 6157-6173, 2008 b.
Zhu, P.: A multiple scale modelling system for coastal hurricane wind damage mitigation, Nat. Hazards, 47, 577-591, 2008. 